Nordic Journal of Language

Teaching and Learning

\title{
Continuing education of English teachers: teachers' translation of new knowledge into the classroom
}

Ingebjørg Mellegård

Høgskolen i Østfold

\section{Introduction}

Professional development of teachers is a complex sphere of investigation. Ostensibly, there is a relatively rich store of studies concerning teachers' learning and development processes. However, when it comes to the actual outcome of professional development courses and the substance of change in teachers' practice, the research is rather meagre.

During their careers, teachers will experience several educational reforms and curricula changes. This means that teachers are required to rethink their own practice at certain intervals and reflect on their beliefs and roles as teachers. Continuing education courses offer great potential as arenas for teachers seeking the latest innovations and provide environments where teachers can reflect on their own practice and participate in a learning community for teachers (Mellegård, 2018).

The current investigation seeks to gain deeper insight into the evolution of primary school teachers' practice through their continuing education course in English. Implementing new knowledge is by no means osmotic; how teachers reflect on new pedagogical knowledge and translate this into practice is at the heart of this research project. Thus, the present study aspires to contribute to broadening academic understanding of the development in teaching methodology experienced by English teachers and resulting from their recently acquired knowledge about learning English.

\section{Context of the study}

In 2009, the Ministry of Education and Research in Norway established a national programme for continuing education and in-service training, Competence for Quality, which enables teachers to gain the now required formal competence as subject teachers. In their guidelines, the Ministry of Education and Research strongly emphasised that these continuing education courses needed to be clearly classroom-oriented by linking practice, theory and new methodology. The Competence for Quality programme was closely connected to the latest national school reform in Norway, the Knowledge Promotion, referred to as LK06 and implemented in 2006. The LK06 has recently undergone a renewal process. The new national curriculum was introduced in 2020, presented as the LK20 and now forms the basis for the Competence for Quality programme. 
These courses were required to be delivered as blended courses combining face to face meetings on campus and the digital classroom. For most of the teachers in this programme, their teaching load has been reduced to allow for the interleaving of studying and teaching, which allows the teachers to try out new methodology consecutively in their classrooms. The number of teachers taking these courses has increased throughout the length of the initiative. The educational authorities have decided that the Competence for quality programme will continue until 2025 adjusted to the requirements of the recent renewal of the Knowledge Promotion reform, LK20, mentioned above.

These courses tend to receive positive feedback from teachers. In one of the latest national evaluations of the Competence for Quality courses, the academic year 2018/2019, 95\% of the primary school teachers report that they are either very satisfied or satisfied with their English course and that the English course has made them reflect on their own teaching practice (Gjerustad \& Pedersen, 2019). Furthermore, in their response to a question about the degree to which they have changed or will change their teaching practice, $87 \%$ of the primary school teachers express a clear "yes" that they will change their teaching in response to the course content and $13 \%$ state that they will change "to some degree" (Gjerustad \& Pedersen, 2019, p. 34). These numbers confirm that the continuing English courses offered through the Competence for Quality programme are a catalyst for reflecting on teaching practice and fostering professional development by their participants.

The first module of the English course at the university college where this research project took place constitutes 15 ECTS-credits and focuses on language skills, language learning and communication. Towards the end of their first semester, the teachers are asked to write a text in which they reflect on their professional development as English teachers. These reflection texts comprise the data for this study and have been investigated to gain deeper insight into the developmental processes in-service teachers experience when taking continuing education and their perceptions of their new knowledge and changes in teaching practices.

\section{Theoretical foundation}

Reflection has long been considered vital for practitioners to explore their own practice and promote their professional growth. However, reflection is complex and diverse; first and foremost, it is crucial to distinguish between descriptive and critical reflection. The former implies merely a description of the practitioners' experiences: what did we do before the English course and what do we do now? The latter type of reflection involves exploring and questioning one's practices to generate a critically reflective approach in one's work (Ho \& Richards, 1993). Boud (2001) defines reflection as "a process of turning experience into learning" (p. 10); reflection is seen as a vehicle to interpret experiences and extract meaning from them to develop deeper insight and take actions accordingly. Reflecting through writing may seem simple and straightforward, but this is seldom the case. Reflection is a skill which needs to be organised and developed over time to serve as an effective device (Leather \& Popovic, 2008). 
According to Larrivee (2000), the critically reflective teacher needs to possess a twofold capacity: critical inquiry and self-reflection. The former capacity involves a careful consideration of one's teaching practices and their implications for students' learning. Furthermore, the capacity for self-reflection goes one step further and adds a thorough examination of the practitioner's personal beliefs and values. These two capacities merge into the concept of critical reflection; being a reflective practitioner means investigating the combination of personal and professional belief systems. Larrivee points out that the process of becoming a reflective practitioner does not involve going through a prescribed step-by-step procedure. Rather, it is described as a "personal awareness discovery process" (p. 296). The potential pitfall, according to Larrivee, is that teachers who do not engage in critical reflection and do not link their teaching decisions to their beliefs may easily end up with fragmented methods and "a bag of tricks" and, hence, remain stuck in unexamined assumptions and beliefs.

Farrell (2013) recognises reflective practice to be the central paradigm in second language teaching today. Teacher reflection is considerably more than "mulling over things before and after classes" (p. 465); reflective practice refers to a critical analysis of the teacher's classroom practice and beliefs. Reflective writing over time is considered an effective tool for engaging teachers in looking more objectively at their classroom practices and may help practitioners to identify patterns in their own practice. Farrell emphasises that it is this noticing that is the springboard for professional development. In its nature, the act of writing allows practitioners to organise their thoughts more systematically. In addition, time is a crucial factor, and reflecting through writing means that teachers can slow down and come back to their reflections at a later point. This mode of reflection can motivate teachers to move from a level where they rely mostly on activities, routines and intuition to a level where their decisions are based on critical thinking.

Closely related to reflection is the interaction between theory and practice. Ertsås and Irgens (2012) argue that it is necessary to expand and redefine the concept of theory to move away from a dichotomous assumption of theory and practice. Using the term theorising directs the focus of attention from pure meta theory as a subject to a dynamic process where theory is not only used but also constructed. Ertsås and Irgens speak of graded theory along a continuum based on Weniger's three-grade-scale from weak to strong theory. The lowest grade, weak theory, is defined as a covered and non-verbalised theory, which is present in all practices. The second grade involves the practitioner's conscious and verbalised theory. However, this theory is not necessarily immediately accessible to the practitioner; reflection and time serve as major tools for bringing it to the surface. Finally, the third and strongest grade of theory refers to meta theory, the theory of theorists, which adds deeper knowledge and wider perspectives to the process of theorising. Theorising is considered the core element in professional development; it allows teachers to engage in processes where they reflect on, analyse and reason their decisions by gradually taking stronger theory into account. This can help teachers to avoid being trapped in experiential teaching alone; conversely, through theorising, their classroom practice will be tied closer to theory and lay the foundation for self-directed professional development. 


\section{Methods and procedures}

This article contains an analysis of a qualitative study which examined the development inservice teachers experienced in their teaching practice towards the end of the first semester of their continuing education course in English. The present study has an emic perspective and focuses on the perceptions of the informants and how they experience the world and create meaning (Postholm, 2010; Savin-Baden \& Major, 2013).

The research method used for collecting data is anchored in personal experience methods; the purpose is to explore and interpret people's experiences in a particular context (Clandinin \& Connelly, 1994; R. Jensen, Sträng, \& Sørmo, 2014). The data are personal texts which the informants wrote nearly half-way through their one-year continuing course in English. Personal documents have several advantages as research material, but also some disadvantages. They represent the informants' genuine words and language without having been influenced by the researcher, which could easily happen in an interview setting. Conversely, interviews allow the researcher to pose probing questions to help the informants develop their arguments further. This is not possible with written texts; the collection of data ends the moment the informants submit their documents.

Another advantage is that personal documents represent data which the informants have produced over time and after consideration. Hence, it is more likely that this data contain more thoughtful and insightful information than interviews would (Creswell, 2009). Moreover, data consisting of personal texts open doors for the researcher to include a larger number of informants compared to different types of interviews (Sträng, 2011). One critical feature of personal documents is that they are not necessarily produced with the purpose of being used as data. Such documents, often referred to as field texts, may have been produced prior to the investigation for a different purpose, but were later used as data when they became relevant for a particular study (Clandinin \& Connelly, 1994). The fact that the original intention was not to collect these field texts as research data may strengthen their authenticity and trustworthiness (Creswell, 2009; Savin-Baden \& Major, 2013).

The scope of study in this research project concerns primary school teachers teaching English at beginner's level. The data for this study were collected from three equivalent English courses for primary school teachers: in the autumn semesters of 2015, 2016 and 2017, a total number of 101 teachers. Due to the delimitation mentioned above, texts written by teachers teaching years $1-4$ were selected. Thus, the data consist of 45 reflection texts. The distribution of years of collection and the teachers' year of teaching is presented in the table below.

\section{Table 1}

Distribution of the informants' year of teaching related to years of collecting data 


\begin{tabular}{cccccc}
\hline $\begin{array}{c}\text { Year of data } \\
\text { collection }\end{array}$ & Year 1 & Year 2 & $\begin{array}{c}\text { Teachers in } \\
\text { Year 3 }\end{array}$ & Year 4 & \\
\hline 2015 & 1 & 3 & 3 & 5 & 12 \\
2016 & 2 & 6 & 6 & 4 & 18 \\
2017 & 2 & 5 & 4 & 4 & 15 \\
\hline Total & 5 & 14 & 13 & 13 & 45 \\
\hline
\end{tabular}

Table 1 shows that there is an approximately equal number of reflection texts written by teachers in years 2-4 whereas the number of teachers in year 1 is considerably lower. Most of these teachers alternate within the years $1-4$. For this reason, the teachers' reflections on their teaching practice may be informed by their accumulated experience of teaching years 1-4. Hence, the year of teaching will not be considered in the findings and discussion below.

The teachers were required to write a reflection text towards the end of their first semester of the English course. This reflection text is part of the course work requirements and needs to be completed and approved before the teachers can sit for their exam. The task is described as follows:

Reflection can be defined as the process of turning experience into learning. With your English course as a starting point, think back over the past months and write a reflection text in which you identify one or more areas where you have experienced development in your teaching practice. Furthermore, discuss the ways this English course draws links between theory and practice; how has theory influenced your perceptions of how children learn English and your role as an English teacher?

Length of text: 800 - 900 words.

These texts were not intentionally written to serve as research data; permission to use these texts as data was sought at the beginning of the second semester. The fact that these texts were an integral element of the course may have made the teachers more guarded in their responses. However, it was clearly communicated to the teachers to reflect in their own words on how their teaching practice had developed. On the other hand, the openness of the question and the individualization of their responses may have had a positive effect on the richness and variation of the data. These reflection texts were created in a well-defined context, which allowed the writers to express their subjective experiences and viewpoints. It is these personal, first-hand experiences which are the object of inquiry.

Analysing qualitative data of this kind is a complex procedure. In qualitative research, the reality is the participants' reality; the researcher gains access to the data through the lenses and subjectivity of the informants (Savin-Baden \& Major, 2013). The personal reflection texts used as data are primary sources; these were produced by teachers in a context with the intention of communicating their reflections on professional development as English teachers. In order to comprehend the meanings of such texts, it is critical that the researcher carefully takes into account both the framework and setting in which the texts were produced (Savin- 
Baden \& Major, 2013) and the relationship between the researcher and the informants (Clandinin \& Connelly, 1994). In the current study, I, the researcher, was the coursecoordinator and one of the lecturers; this relationship naturally contributed to shaping the setting for producing the texts. However, this is not considered a weakness but rather a strength in the way that the researcher's knowledge of the complete environment lays a solid foundation for interpreting what the informants communicate (Creswell, 2009).

The data were analysed inductively in line with open descriptive coding and using a combination of predetermined and emerging codes (Creswell, 2009; Savin-Baden \& Major, 2013). In the coding process, the reflection texts were organised into segments, or chunks of texts, and labelled with a term often found in the actual language used by the informants (Creswell, 2009). Furthermore, the data were coded a second time to ensure that there had not been any shifts in the meaning of the codes during the coding process (Creswell, 2009). A second round of coding would also allow for comparing the data with the codes constantly and, consequently, minimise the risk of overlooking valuable information. The next step taken was to categorise these emerging codes into themes which reflect the dominant ideas found in the data and, hence, constitute the core elements of the data analysis (Savin-Baden \& Major, 2013).

\section{Findings and discussion}

In the following section, the findings and the qualitative content analysis used will be presented according to the emerged themes from the data. Due to the heterogenic nature of qualitative data analyses, the current study takes the position that handling the findings and the discussion simultaneously will lay a solid foundation for a more valid interpretation of the collected data. The content analysis of the data overlaps to some extent with the interpretation; the former involves breaking apart data and revealing patterns while the latter involves uncovering meaning of data (Creswell, 2009; Savin-Baden \& Major, 2013).

The intent of a qualitative study is to understand data in context. This study seeks to explore what development in-service teachers observe in their own teaching practice of English for young learners. The findings are the result of the informants' personal experiences and subjective views of reality. It is critical to acknowledge both the context of the data produced and the subjectivity of what the informants communicate to ensure reliability of the findings (Savin-Baden \& Major, 2013).

The findings are structured according to themes, which became apparent when converting the codes to larger units containing comparable information. Some themes are more outstanding than others, and for reasons of space, it has been decided to give a comprehensive presentation of the three most evident themes: using English more actively in the classroom, turning away from translation and teaching vocabulary - from single words to words in context. Furthermore, the findings are documented in the format of illustrative quotations from the informants' texts to accentuate the context and personal voice of the data. All names have been masked by using pseudonyms. 


\section{Using English more actively in the classroom}

This material reveals that the most marked change teachers notice in their own teaching practice concerns using the target language more actively in the classroom. The following statements capture the essence of a growing awareness many teachers report:

The very first thing I changed in my teaching practice was to go from the teacher who spoke too much Norwegian in the English lessons to become an English-speaking language teacher. This was a big challenge for me, but I grew more certain that this was the way to go. Already in September my pupils did comment on my teaching: "We have never ever spoken this much English in our lessons before. I almost didn't notice we were talking English to each other."

(Harald, teaching year 4)

Language learning is dependent on exposure. The result of this knowledge to me is a more extensive use of English. Being an English teacher for $3^{\text {rd }}$ graders, I had some doubts about the outcome of this new approach. My pupils were not used to me speaking English to this extent, and they still have a very limited vocabulary. I feared they would not understand and because of this become frustrated. My assumptions were proven wrong. My pupils' reactions were merely positive; they seem to be more attentive and eager to speak English now.

(Hilda, teaching year 3)

Both teachers note challenges with increasing their own use of spoken English. Harald expresses a lack of confidence in speaking English as a major barrier and, consequently, had frequently turned to using his mother tongue when teaching English. One reason for this may lie in the fact that teachers taking these continuing education courses have no prior formal competence in English; they have been trained as general teachers, which means they can teach English and other subjects without having specialised in these. Consequently, many of the teachers - 64\% of those teaching years 1-4 - teach English without formally having the qualifications of being English teachers (Perlic, 2019). In the data, many teachers confirm Harald's concerns about not having an adequate standard of English. Undoubtedly, this fear of revealing a poor level of English in the classroom can easily be masked by avoiding speaking English. Today, children are exposed to native English through many different channels, and they react to teachers' mispronunciation, foreign intonation and lack of vocabulary.

Hilda voices concern about young learners' ability to comprehend the message when the teacher communicates predominantly in the target language. She acknowledges the importance of learners being exposed to English but believes that their limited vocabulary at this stage will have a negative effect on their motivation.

Apparently, both Harald and Hilda approve of the positive results they experience from using English more actively with their students. The immediate response from Harald's students is extended communication in English, and this is also noticeable to the students themselves. Hilda admits that her young learners have a greater capacity to understand English than she 
expected them to. These statements clearly demonstrate the absolute necessity for allowing teachers to try out new methodologies during continuing education courses letting them experience the link between theory and practice in their own classrooms (Ertsås \& Irgens, 2012; Munthe \& Postholm, 2012).

Other teachers also reflect on the positive effect on their own language proficiency by using English more actively together with their students:

This course has opened my eyes in many ways. Firstly, the more English I speak, the more confidence I get, and my English is improving. Speaking English all the time when we have been on campus has made me realize that I can manage in the classroom, too.

(Anna, teaching years 2 and 3 )

It seems clear from this that Anna experiences precisely what students do; her own command of English enhances through using the language. From the course meetings on campus, Anna has personal experiences of being a learner, which she transfers to her own teaching; it is obvious that these parallel learning processes have become evident to her.

The data reveal that many teachers reflect on their role as a language model:

I am now striving to teach English through English. Munden \& Myhre say by doing so, I present myself as a role model and thereby encourage my pupils to speak English. This has been a success, not the first day, but gradually more and more of my pupils have started talking and answering in English without me reminding or asking them to.

(Linn, teaching year 4)

I am trying to improve both my own and my pupils' fluency by speaking a lot during the English lessons. My intention is being a better role model than my own teachers were to me by making a positive and motivating learning environment.

(Teresa, teaching year 3)

Being a role model as a language user is obviously not self-evident to Linn and Teresa. The awareness of their impact on the students' language production has grown through gaining deeper insight into language learning theory in addition to noticing the effect of the changes they have made. Teresa recognises the teacher to be a significant factor of the learning environment, and she draws on her own life-experiences as such. Through their critical reflections, they both see the beneficial influence on the students' learning outcomes by being good language models themselves.

\section{Turning away from translation}

Another issue that emerges from the data concerns teachers' practice of translating what they communicate orally to their students in English into mother tongue. The findings reveal that 
teachers reflect critically on the close connection between an active use of the target language and translation:

I used to believe that I had to translate every word into Norwegian for the students to learn English. However, as a consequence of learning that it is important to give the students a "language bath", my perception has shifted. I now only speak English during the English lessons. I can see that some of my students struggle with this. They feel they must understand every word. I try to make it clear to them that it is not important to understand every word but to get the meaning of what is being said. Hopefully, they will get more used to this as time passes, because I am not going to stop.

(Jakob, teaching year 4)

It is worth observing that Jakob's personal belief system has been challenged by new knowledge about language learning; from what he expresses, it appears that he has dealt with it successfully. He turns theory into practice by clarifying to his students that grasping the meaning of a message is superior to comprehending each word. It appears that Jakob is moving away from purely experiential based teaching to applying theory to justify his choices. In other words, Jakob has boarded the process of theorising, moving from weaker to stronger theory when interrogating his own practice. According to Ertsås and Irgens (2012), gradually adopting stronger and stronger theory will provide the practitioners with the necessary tools to reflect critically and gain a meta-perspective on their teaching practice. As a result of his new insight, Jacob seems utterly determined to proceed with his method of using English more actively and reducing translation although he acknowledges that some students will struggle in the beginning. Because of the noticeable positive change of his students' learning outcomes, he is firmly convinced of being on the right track.

There are clear signals in the data that when teachers reduce translating into mother tongue, they turn to using other methodological approaches to help their students create meaning:

I have always thought that if I spoke English in my lessons, I needed to translate almost everything. I now use body language to show what I mean, and my translation is down to a minimum. It turns out my pupils understand more than what both they and I thought they would. Many of them have told me it's fun trying to guess what I'm saying. That's a sign of growing enthusiasm.

(Ingrid, teaching year 2)

When reading texts now, I try not to translate into Norwegian. Instead, we try to retell the text in English. I have seen that when I do not translate, my pupils become eager in their attempt to understand and participate in the retelling. Retelling also forces them to use their vocabulary and adjust it to another context. 
Both Ingrid and Linn describe different learning strategies as tools for meaning-making: visualising the meaning, guessing from the context and retelling texts. On the evidence of these examples, it would thus seem that teachers possess good knowledge of other ways of creating meaning other than translating. However, the fact that they do not use the term learning strategy may indicate that their awareness of these learning strategies as such is masked in practical teaching. Both teachers notice an immediate positive response from their students; less translation motivates the students to participate more eagerly in creating meaning of what is communicated. This provides evidence that these teachers see the link between what they do and the students' learning outcomes; they are in the process of theorising (Ertsås \& Irgens, 2012).

According to Farrell (2013), reflective writing may help teachers identify patterns in their own teaching. The findings reveal evidence of this noticing taking place:

I gave them a relaxing habit by translating. Now I much more try to explain what it means, using English.

(Marie, teaching year 2)

What immediately follows in Marie's reflection text is a series of references to research where she finds support for the change she has made in her teaching. By examining her classroom practice from a more objective point of view, Marie sees that translation had become a habit of hers and not a chosen methodology based on theory. When realising this, she promptly acts and breaks herself of this habit. Apparently, this evidences what Farrell says about noticing patterns being the springboard for professional development (2013).

\section{Teaching vocabulary - from single words to words in context}

During the first semester of the English course, one of the key areas covered is teaching and learning vocabulary. In the data, the teachers articulate forcibly how new knowledge of this field has made them radically rethink their current teaching practice:

After learning about how important collocations are for fluency in the language (Hill, 1991), I have thrown away my "words of the week lists". I am now focussing on what I call "English of the week", which is usually full sentences, common phrases or collocations instead of single words. Why I have not thought about this before is a mystery to me. It is important to learn words, but if the students do not know how to use them to communicate, it is a total waste.

(Jakob, teaching year 4)

I now realise that I have maybe left out the most important part of the procedure of learning new words and that is for the pupils to use the words in meaningful contexts. I have learnt that we must do something with the words in addition to learn to say them and spell them. 
In their reflections, Jakob and Karen clearly demonstrate that their new insight has made them pursue a policy of critical inquiry into their own teaching practice. They do not hold on to their previous practices; they plainly state the need for a change. Jakob supports his arguments convincingly by referring to theory, and both teachers show that they understand the theory of collocations by explaining how they transfer this into practice. What this evidences is that stronger theory provides the teachers with the necessary tools to investigate their teaching practices (Ertsås \& Irgens, 2012).

Other teachers argue the close link between learning collocations and fluency of language:

Learning about collocations and chunks of words has affected my English teaching. The children will build up a repertoire of ready-made language, which will make it easier for them to communicate in English. In my opinion, learning chunks of words should start from day one. Therefore, when we are working on vocabulary in class now, we work with the words in different combinations.

(Siri, teaching year 2)

Siri teaches the early beginners, and she verbalises the importance of putting her new knowledge into action from the very beginning of the pupils' learning process because this will provide them with effective learning strategies helping them out when communicating. New knowledge has made her reflect on the long term-effect of her work with young learners.

On the same theme, this study reveals that many teachers admit that their teaching practice of vocabulary is primarily based on tradition:

The biggest difference is probably my teaching of vocabulary. My focus has moved from learning words to learning chunks of words and collocations. I have often asked myself what the learning outcome of the weekly word test is. Even if I never fully approved of the method, I carried it out in the classroom because it was the common practice. Through theory learnt in this course, I got my doubts confirmed, the arguments I needed and the methods to find better ways for my pupils to learn vocabulary. I am excited to see the long-term results of this change of practice in my class.

(Martha, teaching year 4)

Martha notes that her teaching of vocabulary used to be centred upon weekly word tests, and although she had questioned the pupils' learning outcomes of this practice, she stayed with it. It may be argued that this bears witness to the teacher's lack of awareness about one's teaching practice. However, it is more likely that Martha chose to continue this method of teaching because of an inadequate knowledge of alternatives based upon current research. In Norway, as in many countries, there is a deep-rooted tradition of utilising word lists and word tests in foreign language learning. Apparently, Martha feels doubtful about the usefulness of this but does not know where to turn. However, the English course provides her with relevant theory, which she immediately uses to bring her unconscious knowledge to the surface. 
Martha's change of teaching practice evidences that teachers depend on seeing a high degree of coherence between their own teaching practice and new knowledge to effect changes (Desimone, 2009).

Another dimension of teaching vocabulary revealed in the teachers' reflections concerns the heart of teaching, namely motivation and increased student participation:

When I write English aims in our week plan, I try to find short phrases. Now my pupils manage to ask each other questions about weather conditions, interests, colours and insects. I have given them tools to talk, and it works!

(Marian, teaching year 2)

I have worked on implementing collocations in my vocabulary teaching. The pupils are improving in guessing the meaning of the new words by looking at the words they already know. I think this activates them in a better way than translating or to learn single words every week. I have experienced what Jimmy Hill said about the brain remembering words more easily in chunks because it semantically makes more sense.

(Lisa, teaching year 3)

Both teachers have tested theory and confirmed the desired outcome (Desimone, 2009). Marian reports enthusiastically having instantly noticed that her pupils have enhanced their communicative competence. Lisa specifically links her experiences to a named theorist and convincingly explains theory and how she implements it in her classroom. Again, it is obvious that critical reflection using gradually stronger and stronger theory seemingly results in sustainable development (Ertsås \& Irgens, 2012; Farrell, 2013).

\section{Conclusion}

In the course of this article, teachers' reflections have been investigated to seek deeper knowledge about what development teachers observe in their teaching practices after having acquired new knowledge about the teaching and learning of English. The findings of this study show that teachers take a wide variety of routes when translating new knowledge into practice. In general, the teachers express great satisfaction of being in the process of gaining a higher level of competence through the continuing education course:

On some occasions, I have really felt the lack of fundamental knowledge. After just two, three months, I do register a significant change in my competence. Not that I consider myself a fully qualified English teacher yet, or that I'm in total control of everything, but I really enjoy feeling more competent.

(Margaret, teaching year 4)

Margaret and her fellow teachers in this study have taught English without having specialised in the subject. In the data, many of the teachers, like Margaret, express that this dilemma makes them feel rather insecure and inadequate to facilitate their students to reach the aims expressed in the English curriculum. 
In the Curriculum in English in LK20, the renewal of the Knowledge Promotion school reform, there is a strong focus on communication and using the target language: "The pupils shall experience, use and explore the language from the very start. The teaching shall give the pupils the opportunity to express themselves and interact in authentic and practical situations" (Ministry of Education and Research, 2019, p. 2). This correlates closely with the findings in this study. The teachers report that new knowledge about the importance of using English more actively in their teaching and facilitating for students to build up their vocabulary systematically from isolated words to phrases has fostered development in their teaching practices. This means that the continuing education course not only enables the teachers to experience the link between theory and practice but also to see that their new knowledge provides help to achieve the aims in the curriculum.

In the light of the findings in the present study and the discussion above, there is evidence for arguing that successful continuing education courses for teachers demand a pedagogic philosophy where the connection between theory and practice is convincingly demonstrated. One of Desimone's critical components of effective professional development is coherence between teachers' learning and teachers' existing knowledge and beliefs (2009). From the data of this study, it becomes evident that teachers experience this connection in the English course and use it in their reasoning.

Finally, the attention returns to the concept of theorising. The results confirm the process of theorising as a tool and catalyst for helping the teachers not only reason why to make changes but also to choose one methodology over another. This is closely connected to where teachers search for new knowledge. In Karen Jensen's study (2008), teachers express that their most important source for new knowledge comes from sharing experiences with colleagues. According to Ertsås and Irgens, experiential learning alone is not adequate to become a professional teacher. The results from this investigation show that exposing teachers gradually to stronger and stronger theory concurrently with the subject matter content and possibilities for trying out new methodology is a successful route for teachers' professional development to take place.

\section{List of references}

Boud, D. (2001). Using Journal Writing to Enhance Reflective Practice. New Directions for Adult and Continuing Education, 2001(90), 9-17.

Clandinin, D. J., \& Connelly, F. M. (1994). Personal Experience Methods In N. K. Denzin \& Y. S. Lincoln (Eds.), Handbook of Qualitative Research (pp. 413-427). USA: Sage Publications.

Creswell, J. W. (2009). Research Design. Qualitative, Quantitative, and Mixed Methods Approaches. USA: SAGE Publications.

Desimone, L. M. (2009). Improving Impact Studies of Teachers' Professional Development: Toward Better Conceptualizations and Measures. Educational Researcher, 38(3), 181199. 
Ertsås, T. I., \& Irgens, E. J. (2012). Teoriens betydning for profesjonell yrkesutøvelse. In M. B. Postholm (Ed.), Laereres laring og ledelse av profesjonsutvikling (pp. 195 - 215). Trondheim: Tapir Akademisk Forlag.

Farrell, T. S. C. (2013). Teacher self-awareness through journal writing. Reflective Practice, 14(4), 465-471.

Gjerustad, C., \& Pedersen, C. (2019). Deltakerundersøkelsen for larere

Høgskolen i Østfold (2019:19). Retrieved from Oslo: https://www.udir.no/contentassets/81baee942541493cac2765450d3304ec/videreutdan ning_larere_deltakerundersokelse_2019.pdf

Ho, B., \& Richards, J. C. (1993). Reflective thinking through teacher journal writing: Myths and realities. Prospect: A journal of Australian TESOL, 8, 7-24.

Jensen, K. (2008). Nye utfordringer i kunnskapssamfunnet. Kunnskapsutvikling og faglig oppdatering hos lærere, sykepleiere, dataingeniører og revisorer. Bedre skole(2008:4), 54-57.

Jensen, R., Sträng, R., \& Sørmo, D. (2014). Kvalitetsutvikling fra klasserommet: Oppsummering av LOV-prosjektet. Vallset: Oplandske bokforl.

Larrivee, B. (2000). Transforming Teaching Practice: Becoming the critically reflective teacher. Reflective Practice, 1(3), 293-307.

Leather, S., \& Popovic, R. (2008). Time for reflection. English Teaching Professional(55), 57-59.

Mellegård, I. (2018). Å være etter- og videreutdanner av lærere. Bedre skole, 1, 77-82.

Ministry of Education and Research. (2019). Curriculum in English. (ENG01-04). Retrieved from https://www.udir.no/lk20/eng01-04?lang=eng

Munthe, E., \& Postholm, M. B. (2012). Læreres profesjonelle læring i skolen. In M. B. Postholm, P. Haug, E. Munthe, \& R. J. Krumsvik (Eds.), Laerere i skolen som organisasjon (pp. 137-154). Kristiansand: Cappelen Damm Høyskoleforlaget.

Perlic, B. (2019). Larerkompetanse i grunnskolen. Retrieved from Oslo: https://www.ssb.no/utdanning/artikler-ogpublikasjoner/ attachment/391015? ts $=16 \mathrm{~b} 93 \mathrm{~d} 5 \mathrm{e} 508$

Postholm, M. B. (2010). Kvalitativ metode. En innføring med fokus på fenomenologi, etnografi og kasusstudier. Oslo: Universitetsforlaget.

Savin-Baden, M., \& Major, C. H. (2013). Qualitative Research: The essential guide to theory and practice. Oxford: Routledge.

Sträng, D. R. (2011). En flerstämmig kulturanalys. (Phd). Karlstad University, 